\title{
TRANS-SAHARAN GOLD TRADE AND BYZANTINE COINAGE
}

\begin{abstract}
David W Phillipson, FSA
David W Phillipson, II Brooklyn Terrace, Threshfield, Skipton, North Yorkshire BD23 5ER, UK. Email: dw.l.phillipson@btinternet.com

It is often argued that northward trade in gold from sub-Saharan West Africa began after the establishment of Islamic control late in the seventh century AD. This paper questions that conclusion, and suggests that minting at Carthage of the Byzantine gold coins known as globular solidi was related to the acquisition of metal through developing trans-Saharan contacts. Political developments in the late sixth century may have interrupted the supply of gold to Byzantine Carthage; this problem intensified during the following decades when production of globular solidi began. It is suggested that trans-Saharan imports comprised gold that was cast, for export and apparently also for local circulation, at Tadmekka in north-eastern Mali and perhaps elsewhere, into lumps of standardised weight calculated to meet the needs of the Byzantine mint at Carthage. Preliminary archaeometallurgical investigations provide some degree of support for this hypothesis, and further analyses are planned that may identify the sources of the gold minted in seventh-century Carthage. If and when such detail becomes available, it may have major implications for our understanding of the nature and instigation of ancient trans-Saharan connections.
\end{abstract}

\section{THE TRANS-SAHARAN GOLD TRADE}

Rich gold deposits in sub-Saharan West Africa have been exploited by indigenous peoples for many centuries. ${ }^{\text {I }}$ Since at least one thousand years ago, some of this gold has been exported to the circum-Mediterranean world (see fig I) where it has been widely used for coinage and other purposes. The earliest written records of this trade occur in Arabic texts ${ }^{2}$ produced long after the Islamic ${ }^{3}$ conquest of North Africa at the end of the seventh century $\mathrm{AD}$ (late first century $\mathrm{AH}) ;{ }^{4}$ they refer to overland transport, but do not indicate when that practice began. Documentary sources, however, clearly show that by the ninth/tenth century it had intensified and achieved significant regularity. Not until the fifteenth century did Europeans establish a sea-route to West Africa and gain control over northward conveyance of the region's gold. Although this outline is widely accepted, there is little consensus about the details, particularly for the earlier periods. Reliance on Arabic

I. For example, MacDonald 20 I.

2. The earliest such texts were compiled in the ninth century AD (third century AH), although there are indications that some may incorporate material that originated significantly earlier (Levtzion and Hopkins I98I, v).

3. In deference to established usage, the term 'Islamic' is retained in this paper to designate aspects of culture practised by Muslim societies even in contexts not usually seen as religious.

4. Dates in this paper, unless clearly specified otherwise, are given in years AD. Where Muslim communities or individuals were involved, the date $\mathrm{AH}$ is also provided. 


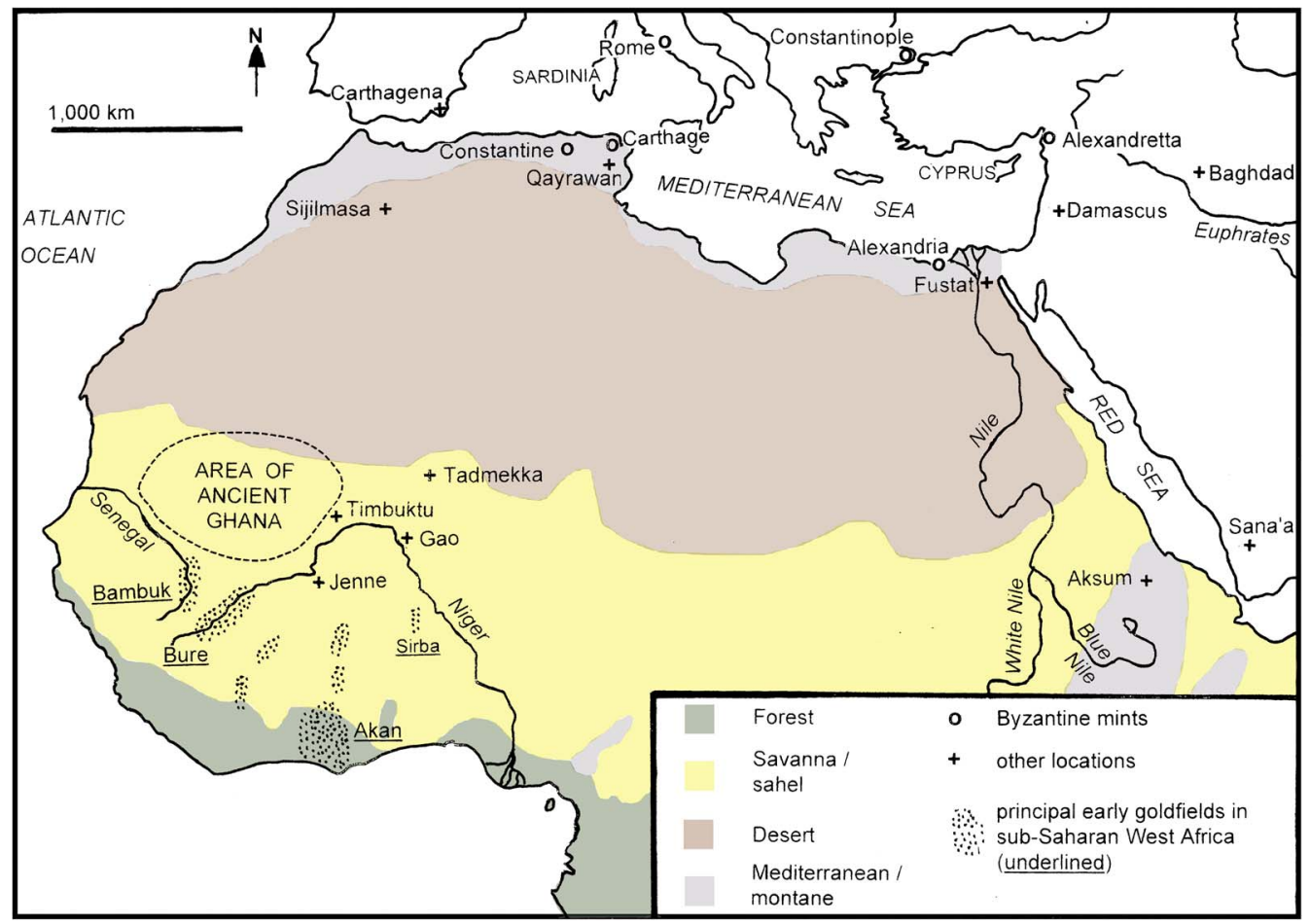

Fig I. Map of North and West Africa, the Mediterranean basin and the Middle East, showing principal locations mentioned in the text. For Africa only, simplified present-day vegetation patterns are indicated. Map: the author, with the advice and assistance of Charlotte Fox and the late Brian Foxley.

texts has led many scholars to assume that the trans-Saharan gold trade arose during Islamic times. Consequently, the search for numismatic evidence has been largely restricted to the study of Umayyad and Abbasid dinars. ${ }^{5}$

West African production of gold may probably be traced back to the middle centuries of the first millennium, but primary archaeological evidence is sparse and inconclusive. The principal regions where indigenous exploitation seems to have taken place have been mapped by several scholars. ${ }^{6}$ They include the Bambuhu (Bambuk), Konkadugu and Gangara (Wangara) areas at the headwaters of the Niger and Senegal rivers, ${ }^{7}$ both of which have auriferous sediments further downstream. The Sirba tributary of the Niger may likewise have been significant. Much of the gold has been recovered from alluvia and other secondary deposits, exploitation of which has left little permanent record. ${ }^{8}$ In most cases, the quartz pipes from which the alluvial gold was ultimately derived have long ago been destroyed by erosion. There has been remarkably little detailed metallurgical or technological study of locally produced gold artefacts, few of which come from recorded and datable archaeological contexts. ${ }^{9}$

5. See, however, Jonson et al 2014; also, Mattingly et al 2015.

6. For example, Mauny I96I; Garrard I980, fig I; Devisse I993; see fig I, here.

7. Curtin 1973,625 .

8. The sites in Burkina Faso described by Kiéthéga (1983) provide an exception.

9. However, for an informative overview, see Garrard I989. Conclusive evidence for the recovery of gold in sub-Saharan West Africa prior to the ninth century AD is notably lacking. 


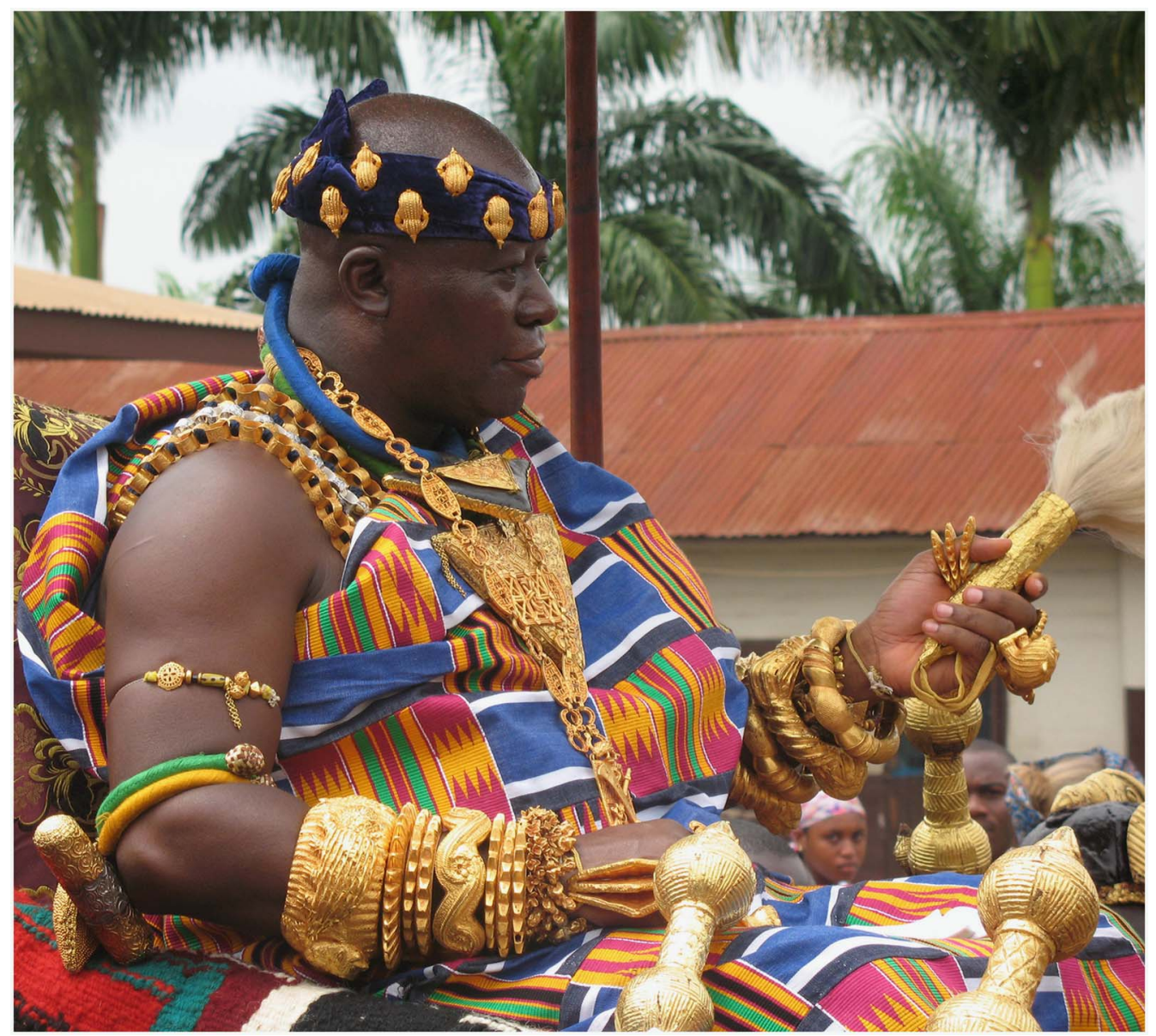

Fig 2. West African gold regalia: His Majesty The Asantehene, carried in a palanquin at the durbar held in 1999 to mark the tenth anniversary of his accession to the Golden Stool. Carrying a fly-whisk, he was surrounded by bearers of swords, the golden handles of which may be seen in the photograph. Many of his golden adornments are re-castings of those worn by his predecessors. Photograph: Gordon

Frimpong, obtained through the good offices of Professor Malcolm McLeod.

Several factors have contributed to the prevailing dearth of information. Much West African gold occurs in areas that are not easily reached by outsiders. Those responsible for the exploitation of the deposits and/or the export of their product have been understandably reluctant to divulge details that may encourage competition. Much of the produce, if not exported, has been retained as personal wealth and/or in traditional rulers' custody (fig 2 ); ${ }^{\text {IO }}$ both categories continue to be protected from scrutiny. ${ }^{\text {II }}$

Io. For example, McLeod I98I, 72-III.

II. This paper is about gold, and is not the place to offer more general comments on archaeological evidence for trans-Saharan trade. The factors noted above have probably contributed to the scarcity of such evidence, while emphasis on gold will have diverted attention from exchange, both local and trans-Saharan, in other commodities (see, in particular, McIntosh I98I; McIntosh and McIntosh 1981; Fenn et al 2009; Wilson 2012; Fentress and Wilson 2016). Although evidence 
The initial date for the northward transport of West African gold across the Sahara has long been a matter of controversy. ${ }^{{ }^{2}}$ Evidence that it began prior to the establishment of Arab rule has generally been accorded little weight, ${ }^{\mathrm{I}}$ and it is salutary to speculate why this should have been so. As noted above, a prime source of information has been Arabic writings of travellers and historians from the ninth century AD (third century AH) onwards. ${ }^{\mathrm{I}}$ Relatively few of these writings were based on first-hand observation, although, as noted below, there are indications that some of them may incorporate material that originated well prior to the compilations in which they are preserved. ${ }^{15}$ Interest in the pre-Islamic past has not been a general feature of Arabic culture and is still often discouraged in that context.

A trans-Saharan gold trade was certainly under way from the ninth century AD onwards, but indications that it may have begun earlier remain inconclusive. Arabic records cannot be expected to throw significant or trustworthy light on the possibility of its existence in preIslamic times, although a statement by al-Fazari, ${ }^{16}$ writing at Baghdad late in the second century $\mathrm{AH}$, has been interpreted as indicating that the Ghana kingdom and - by implication - outsiders' knowledge of its wealth in gold began before Arab contact was established. ${ }^{\mathrm{I}}$ Writing $c 320 \mathrm{AH}$, al-Hamdani, a native of Yemen known to have travelled widely in the Arabian peninsula and in Iraq but not farther afield, recorded a statement by the master of the mint at Sana'a that 'the richest gold mine on earth [was] that of Ghana' ${ }^{18}$ More than a century later, the wealth of Awdaghast in Ghana was confirmed by al-Bakri, ${ }^{19}$ albeit from second-hand report.

Al-Bakri's compilation, prepared $c$ IO68 (c $446 \mathrm{AH}$ ) but including material from earlier sources, noted that, at Tadmekka, ${ }^{20}$ "their dinars are called "bald" because they are of pure gold without any stamp', ${ }^{2 \mathrm{I}}$ and at Sijilmasa ${ }^{22}$ 'gold ... is bought or sold ... by number, not

relating to the first millennium $\mathrm{AD}$ is understandably sparse (Haour 20II), several commentators (for example, Brett and Fentress 1996, 217) have argued that, at least in later times, slaves may have been traded to a value even exceeding that attained by gold. Raw materials are less likely to be recognised in archaeological contexts than are manufactured items imported from elsewhere (for example, Mattingly 20I I; Mattingly et al forthcoming), resulting in a distorted understanding of inter-regional commerce whether formal or informal. These factors may give rise to a view that such transactions were less balanced and mutually beneficial than was, in fact, the case.

I2. Bovill I968; Mauny 1978; Garrard I982; Devisse I988; Insoll 2003, 209-50; for a recent overview, albeit brief, see Mitchell 2005, I43, I48-9.

13. For example, Swanson 1975; Spufford 1988, I63-86; Nixon 2009; Austen 2010, 23-48.

I4. Cuoq 1975; Levtzion and Hopkins I98I.

I5. It was unusual for the compilers to specify their sources (Wansbrough I970).

I6. Cited by al-Mas'udi; see also Levtzion I973, 3-28, I24-48; Levtzion and Hopkins I98I, 30-2.

17. Mentions of Ghana at this period refer, of course, to the ancient polity located in an area now mainly comprised within the modern states of Mali and Mauritania (see fig I; Levtzion I973; Insoll 2003, 224-3I; Phillipson 2005, 240, 275-7; Connah 2016, I77, I9I-2) rather than to the former Gold Coast colony that gained independence as the Republic of Ghana. The ancient state gained its reputation as a source of gold, not as a primary producer, but through functioning as a highly effective intermediary in the onward transmission of metal that had originated farther south.

18. Levtzion and Hopkins I98I, 29. For the misunderstanding implied by this statement, see n. I7.

19. Levtzion and Hopkins I98I, 79-84. Awdaghast, usually identified with ruins at Tegdaoust in southern Mauritania, seems to have been the principal settlement of ancient Ghana.

20. Tadmekka (es-Suk, Essouk), in what is now north-eastern Mali (see fig I), is located $c 300 \mathrm{~km}$ north-northeast of Gao. Archaeological investigations have been conducted there by Dr Sam Nixon (discussed in the Archaeological Evidence from Tadmekka section).

2I. Levtzion and Hopkins I98I, 85.

22. Believed to have been established in the mid-eighth century (early-second century AH), Sijilmasa was a major trading settlement in what is now south-eastern Morocco. Research conducted there 
by weight, whereas leeks ... are sold by weight, not number' ${ }^{23}$ Textual evidence thus suggests that, by the eleventh century, gold represented a medium of exchange in the sudanic belt of West Africa; ${ }^{24}$ at least in some places it circulated in pieces of standardised weight, although these bore no stamped markings such as would have transformed them into true coins. ${ }^{25}$

An anonymous contemporary of al-Bakri recorded a second-hand account that a merchant annually despatched from Tadmekka, to an unspecified destination, a consignment of sixteen leather bags, each containing 500 'dinars'. ${ }^{26}$ The weight of such a consignment, at $4.5 \mathrm{~g}$ per 'dinar', would have amounted to $c 2.25 \mathrm{~kg}$ per bag, or about $36 \mathrm{~kg}$ in total - only part of a single camel-load. ${ }^{27}$ It appears that none of these 'bald coins', which circulated locally but were also transported elsewhere, has survived.

In this context, the writings of Timothy Garrard ${ }^{28}$ have not always received the consideration that they deserve. ${ }^{29}$ Garrard (1943-2007), who was Senior State Attorney for the Republic of Ghana, balanced evidence from a wider range of sources than more focused scholars were able to consider: textual, oral, numismatic, ethnographic and archaeological, from African, Arabic and Graeco-Roman contexts. ${ }^{30}$ Particular attention is due to his conclusion $^{3 \mathrm{I}}$ that the weight-standard employed in many West African regions for the measurement of gold dust was ultimately based on the late Roman/Byzantine unit of $4.5 \mathrm{~g}$, which, as will be shown below, was precisely the weight of the sixth/seventh-century gold coins called solidi. By the end of the seventh century, the weight of the solidus had widely been reduced to $c 4.25 \mathrm{~g}$, and it was at this level that the standard was adopted by Arabs as that of their own gold currency-unit, the dinar. Thus, the evidence of weight-standards, like the archaeological record, provides no conclusive indication that gold-production in subSaharan West Africa began in pre-Islamic times.

\section{ARCHAEOLOGICAL EVIDENCE FROM TADMEKKA, MALI}

Excavations at this site in 2005 by Dr Sam Nixon have been noted above. Clay objects recovered were described as 'coin-moulds', it being argued that they had been used to produce standardised weight lumps of gold. ${ }^{32}$

during the I980s and I990s by Professor Ronald Messier has recently been published (Messier and Miller 2015) and is being resumed under the direction of Professor François-Xavier Fauvelle.

23. Levtzion and Hopkins I98I, 66.

24. This point was emphasised in Nixon 2009.

25. Contra Nixon 2009; Nixon et al 20II. For consideration of earlier but comparable processes in another geographical region, with emphasis on the distinction between money and coin, see Balmuth 1975, 2001; Price 1983.

26. Levtzion and Hopkins I98I, 90.

27. For the weight of the 'dinar', see Garrard 1982. For discussion of the archaeological visibility of evidence for inter-regional trade, see n. II. See Discussion section for further detail on camels.

28. Notably Garrard 1980, 1982, 1988.

29. But see MacDonald 201 I.

30. Garrard's (I982) speculations on Roman-period access to sub-Saharan gold are, however, implausible; they were based on a misunderstanding of mechanisms for taxation and precious metal circulation within the Roman Empire.

3I. Ibid. The critique by Hewson (I980), kindly brought to the author's attention by Professor Malcolm McLeod, was based on an earlier work in which Garrard (1972-3) had sought to establish the metrological system on which the well-known Asante gold-weights were based. It does not, in the author's opinion, negate the validity of the more general correlation that was subsequently proposed, and which is cited here.

32. See n. 20; Nixon et al 20I I; see also Nixon 2009; Rehren and Nixon 2014. 

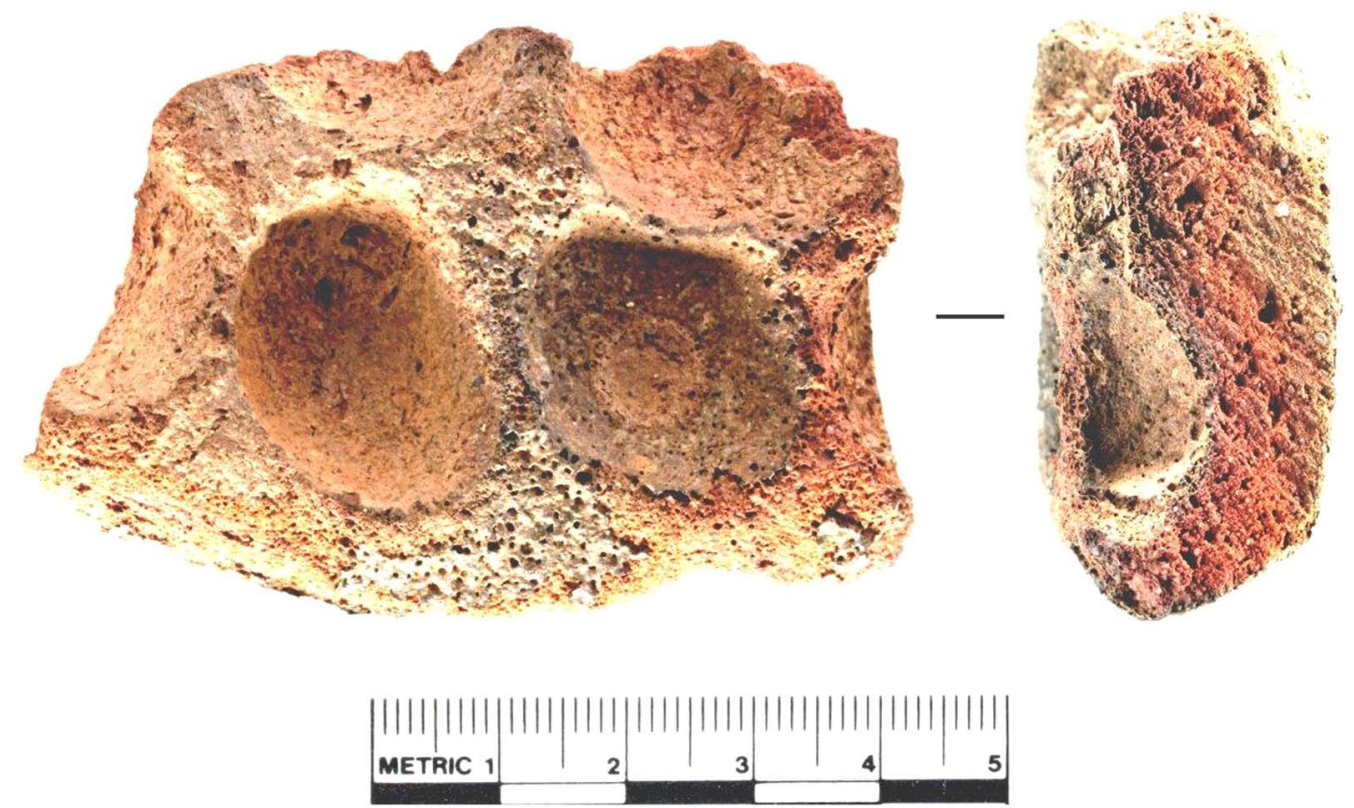

Fig 3. A mould-fragment from Tadmekka: left - view, showing overall vitrification and 'ghost' of casting in right-hand complete cavity; right - section. In both images, the original edge of the artefact is at the bottom. Photograph: supplied by Dr Sam Nixon and reproduced with his kind permission.

The so-called 'coin-moulds' (actually, it is proposed below, moulds for producing the metal blanks from which coins were subsequently produced) were excavated from horizon 6 in unit EKA. Nixon attributed this horizon to his period 2, for which radiocarbon dates suggest an age between the mid-eighth century and the mid-tenth. ${ }^{33}$ Three mouldfragments (fig 3$)^{34}$ were recognised at Tadmekka, being slabs of porous low-fired clay with sub-conical depressions that averaged some $10 \mathrm{~mm}$ deep and $20 \mathrm{~mm}$ wide at the top. They were found associated with additional evidence for the working of metal, including gold of remarkable fineness, over a prolonged period. The dating, while undoubtedly broadly correct, will - it is hoped - be subject to refinement in future. ${ }^{35}$ Nixon argued that the products of these moulds served as 'coins', but this is a misleading use of the word, following Pory's sixteenth-century translation of Leo Africanus' Italian text; ${ }^{36}$ in current usage, a true coin is a piece of metal bearing a design or other officially sanctioned mark that either guarantees its weight and fineness and/or indicates its status as legal tender. ${ }^{37}$ There is absolutely no indication that the pieces of metal produced at Tadmekka

\section{Nixon 2009.}

34. Nixon et al 201 I, figs $6-9$.

35. Nixon et al 20I I, I,357, implied that the Tadmekka sequence began before the eighth century. For further detail, see Discussion section.

36. Brown I896, 825. The subsequent recognition of Leo's Arabic 'Urtext' (Rauchenberger I999, see especially 208-IO) necessitates no modification of these conclusions.

37. Works such as the Oxford English Dictionary and Encyclopaedia Britannica confirm general acceptance that a stamped indication of guarantee is a defining characteristic of a coin. It is surprising that several authors of introductory numismatic texts (for example, Grierson 1975) have not 
were provided there with such designs. On the contrary, Nixon and colleagues have quoted al-Bakri's eleventh-century Arabic account to the effect that 'bald coins' of gold (that is, pieces of metal bearing no designs but probably standardised in weight) circulated locally at Tadmekka; ${ }^{38}$ similar observations were recorded in the sixteenth century by Leo Africanus at Jenne and Timbuktu. ${ }^{39}$ Both al-Bakri and Leo strongly implied that the weights of these objects were standardised, although they bore no clear literal or symbolic indication to that effect.

It should here be noted that $4.5 \mathrm{~g}$ of pure gold would constitute a volume - depending on temperature - between 230 and $260 \mathrm{~mm}^{3}$, equivalent to a sphere between 7.6 and $7.9 \mathrm{~mm}$ in diameter. ${ }^{40}$ The illustrations of the Tadmekka 'coin moulds' (see fig 3 ) indicate that they would have been well-suited to the production of metal pieces of this size. At the base of one depression (on specimen EKA-95) was observed 'a circular pattern in the vitrification, almost certainly the "ghost" of a molten coin disc"4I (see fig 3, left). Calculations based on the published photographs indicate that this circular 'ghost' is approximately $8 \mathrm{~mm}$ in diameter, which is very close indeed to the dimensions suggested above. An item from the same context as the moulds was interpreted as a fragment of a crucible; prills extracted from it contained 98 per cent gold. ${ }^{42}$

The conclusion that these moulds were used for producing small gold sub-spheroids is not contradicted by a recent metallurgical consideration of the processes involved; ${ }^{43}$ there is, however, no evidence to support designation of the place at Tadmekka where such processes were carried out as a 'mint'. ${ }^{44}$ Below, it is argued that the primary reason for the production of these gold objects, which may have begun somewhat earlier, was for longdistance transport to a distant mint where they were eventually stamped with appropriate designs and transformed into true coins, as indicated by Nixon and his colleagues. ${ }^{45}$

It thus seems highly likely that - by at least the eighth/ninth century - uniform gold sub-spheroids were produced in quantity at Tadmekka and perhaps elsewhere in the West African sudan, and that their standardised weight was probably already at the $4.5 \mathrm{~g}$ level. The implications of this conclusion may now be considered in the context of both Byzantine and early Islamic numismatics.

thought it necessary to reiterate such a definition. A coin is a type of money: for the distinction, see The Trans-Saharan Gold Trade section and n. 25. Lumps of metal, standardised in weight but bearing no stamps, have been designated 'dumps' by some numismatic writers (for example, Robinson I951; Price 1983).

38. Nixon et al 20I I, I,354-5; Levtzion and Hopkins I981, 85 .

39. Brown $1896,822,825$.

40. I am grateful to Dr Tacye Phillipson for these calculations.

4I. Nixon et al 20I I, I,360, figs 7 and 9B.

42. Nixon et al 20II. Professor Kevin MacDonald (pers comm 2015) has drawn my attention to lesswell documented discoveries of apparently similar moulds elsewhere in the West African sudan; the only relevant publication of which I am aware is that by Vanacker (1984, cited by Nixon et al 20II, I,359), which interpreted specimens from Awdaghast (see n. I9) as having been used in the manufacture of glass beads. Similar objects of comparable age have been recorded far to the east from Aksum in Ethiopia (Littmann et al 1913, 2, 224; Wilding 1989, 313), but comprehensive documentation is not available (Phillips 20II, 389-92). Examples from pre-Roman Iron Age Europe are somewhat earlier and have been subject to more intensive research, as recorded in Landon (2016).

43. Rehren and Nixon 2014.

44. Ibid, 40.

45. Nixon et al 201 I, I,362-6. 


\section{BYZANTINE COINAGE}

The gold coinage of the Byzantine (East Roman) Empire was produced in huge quantities, providing some measure of stability to the financial affairs of an area that often extended far beyond Constantinople's direct political control. ${ }^{46}$ In contrast with the rapid fluctuations and generally poor quality of the copper issues, ${ }^{47}$ and with the comparatively rare and intermittent issues in silver, the abundant gold coinage maintained remarkable stability in its weight and purity. ${ }^{48}$ Its basis was the solidus, introduced in the coinage reform of AD 3 I 2 under Constantine the Great, and struck at a rate of 72 to a Roman pound (324g), each coin thus comprising $4.5 \mathrm{~g}$ of gold. ${ }^{49}$ Despite short-term and often local fluctuations and changes in the area(s) within which it circulated, both its weight and over-98 per cent fineness were maintained with remarkable standardisation and stability until the eleventh century. ${ }^{50}$

Gold fractions of the solidus, the semissis (half) and tremissis (one-third), were also struck at several mints in variable quantities at different times. They are distinguishable from the solidus more readily by weight than by diameter. Until the late-seventh century, to aid their recognition, the fractional denominations employed distinctive designs: ${ }^{5 \mathrm{I}}$ the obverses, for example, usually retained the imperial portrait in profile, in contrast to the solidus where a frontal or near-facing portrait had been the norm since the early fifth century.

It is clear that production of gold coins was subject to closer centralised control and much greater care than the copper. The number of mints in operation at any one time varied considerably, but coinage production at Constantinople was usually on a much larger scale than elsewhere. Designs were in most cases decreed by a central authority, but locally produced dies could result in variation between mints in detail and style. ${ }^{52}$ Although there were exceptions, particularly on the copper, places of mintage were rarely indicated on the coins themselves. Identification of places where gold coins were minted has thus been based largely on such factors as style and find-spot. Despite much broad agreement, ${ }^{53}$ numerous points of controversy remain, and evaluation is often hampered by lack of detailed publication of the evidence on which attributions have been based. ${ }^{54}$

There is considerable variation in the precision with which Byzantine coins can be dated. The regnal dates of the rulers are known from historical sources. In some cases, the rulers' ageing was reflected in their portraits, as with the growth of Constans II's beard during the course of his $64 \mathrm{I}-68$ reign (fig $4 \mathrm{c}, \mathrm{d}$ ). ${ }^{55}$ The date of mintage was rarely indicated on the coins themselves, an obvious exception being the large 40-nummi copper coins

46. Georganteli and Cook 2006.

47. The base-metal coins have frequently been referred to as bronze, but this usage is rarely supported by metallurgical analyses and the more general term is here preferred.

48. Grierson I96I, I982, I4.

49. $4.5 \mathrm{~g}$ of gold was deemed equivalent to 24 carats. Although currently used to indicate the purity of gold, the carat was originally a measure of weight and is still employed thus for diamonds.

50. Grierson I96I.

5I. For example, Wroth 1908; Morrisson 1970.

52. For example, Grierson I950a.

53. For example, Hahn I973-8I; Sear 1987. The inscription CONOB in the exergue of many Byzantine gold coins, unlike its counterparts on earlier Roman issues, did not identify the place of mintage (see Grierson 1982, 20-I).

54. The detailed and careful work of Morrisson should be excepted from this criticism.

55. Depiction of regalia was likewise employed to differentiate the status of individuals (see also n. 76), and this can provide independent dating evidence for the coins. 


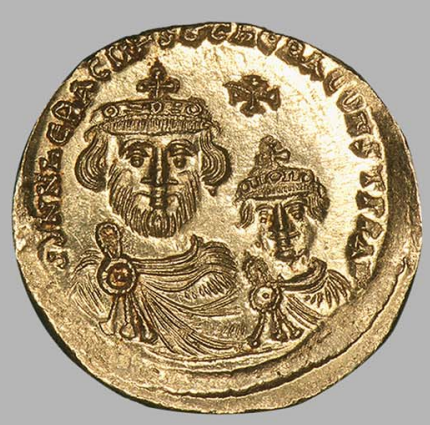

(a)

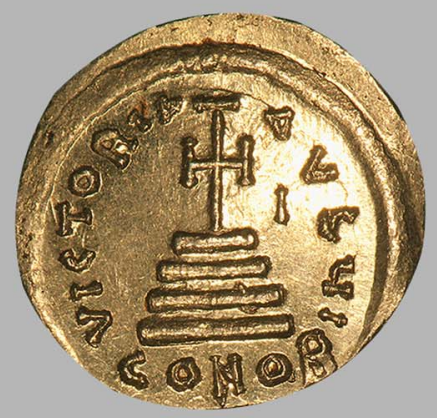

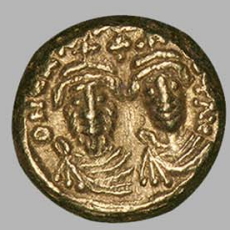

(b)

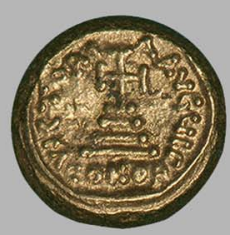

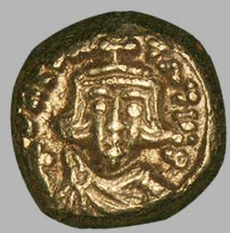

(c)

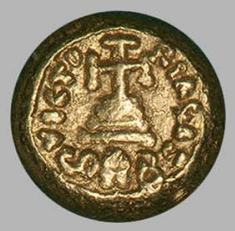

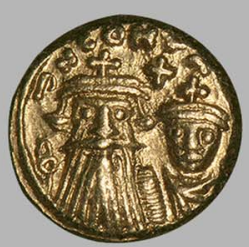

(d)

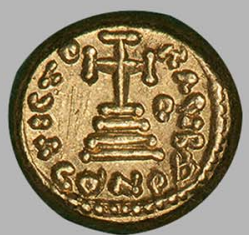

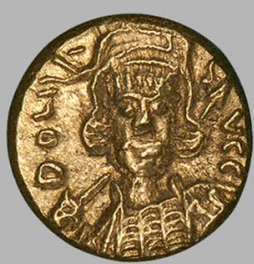

(e)
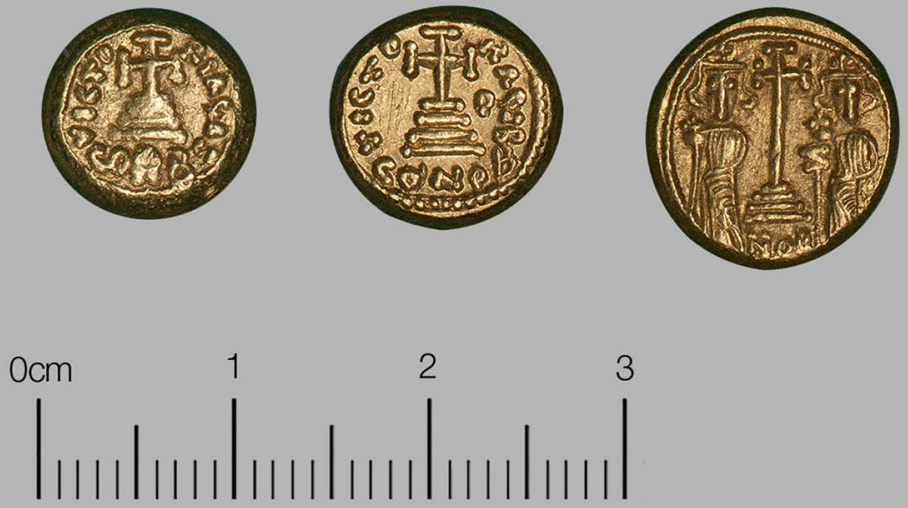

Fig 4. Regular and globular solidi compared: a) Constantinople-minted 'regular' solidus (MIB Io, 4.49g) of Heraclius and Heraclius Constantine, dated c 629-32; b) Carthage-minted globular solidus (MIB 85[3], 4.35g) of Heraclius and Heraclius Constantine, indiction $\mathrm{I} \Gamma=\mathrm{I} 3(624 / 5$ or $639 / 40)$; c) Carthage-minted globular solidus (MIB $c f 56,4.47 \mathrm{~g}$ ) of Constans II, indiction $[\Delta] \Sigma=6(647 / 8)$; d) Carthageminted globular solidus (MIB 67[I], 4.37g) of Constans II and Constantine IV, indiction IB = I2 (653/4); e) Carthage-minted globular solidus (MIB 22[3], 4.25g) of Constantine IV, indiction $Z$ (reversed) $=7(678 / 9)$. 'MIB' references are to the type numbers in Hahn 198I. Note that all coins illustrated in this paper are shown at exactly the same scale. Photograph: John Vessey. 
introduced in 538/9 under Justinian $\mathrm{I} .{ }^{56}$ Two methods were employed: the emperor's regnal year, and the more complicated system of indictions - a fifteen-year cycle, beginning I September, on which elements of the Byzantine tax-system were based. ${ }^{57}$ Fortunately for the purposes of this paper, the gold coins minted at Carthage during the period under prime consideration usually bore precise indictional dates. ${ }^{58}$

Following the collapse of the Roman Empire in the West, the Latin language and Roman script were retained in Byzantine coinage inscriptions for several centuries. Gradually and inconsistently, Greek forms were adopted from the mid-seventh century. More usually, Greek letter-forms were incorporated into Latin words, perhaps indicating that die-engravers received little literate supervision. Latin numerals were usually employed for regnal years, but Greek ones for indictions.

It is with the gold solidi minted at Carthage during the seventh century that this paper is primarily concerned. The Carthage mint had commenced operation under Byzantine auspices one year after the re-conquest of its territory from former Vandal rulers in 533, during the reign of Justinian I. From the start, coins were struck in gold, silver and copper, all following the pattern that then prevailed throughout the Empire. In 539/40, the Carthage mint followed Justinian's coinage reform. Thereafter, until the reign of Focas (6o2-8), the Byzantine coinage issued at Carthage followed the general pattern of that produced at the Empire's other mints, although the gradual reduction in diameter that ultimately led to the 'globular' solidi discussed in the following section may be discerned as early as the reigns of Maurice (582-602) or even, it has been suggested, ${ }^{59}$ Justinian I.

In the summer of 608 , the Carthage mint broke away from Constantinopolitan control. ${ }^{60}$ This was occasioned by the seizure of local power by the exarch of Africa, named Heraclius, who was initially careful not to be seen as presenting a direct challenge to the admittedly ineffective power exercised by Focas at the imperial capital. Shortly afterwards, support for the Carthaginian usurpation spread eastwards; by the autumn of 6ro the insurrection had reached Constantinople, where Focas was deposed and executed, the Patriarch crowning Heraclius' homonymous son as emperor. Only then did the Carthage mint revert to issuing coins with designs endorsed by the authorities at the capital. The younger Heraclius reigned alone until 613, when his son Heraclius Constantine was elevated as co-emperor.

\section{'GLOBULAR' SOLIDI}

Here, this paper looks at the highly distinctive series of gold coins known almost exclusively from North African find-spots ${ }^{61}$ and generally - if not very accurately - known in the

56. See illustrations in Sear 1987, 60, dust-jacket; see also Grierson I982, 60-I; Metcalf I960.

57. Useful summaries are provided by Grierson (I950a, I982, 24-5) and by Sear (I987, 3I). Use of indictions for dating was remarkably widespread and long-lived.

58. The practice seems to have begun in the last regnal year of Maurice, 58I/2 (Whitting I966; Hendy I970, I44). When a reign spanned more than one indictional cycle, numismatic evidence sufficient to distinguish these is usually available (Whitting 1973, 134). A good example is provided by the coin illustrated here in Fig $4 \mathrm{~b}$. It was struck under Heraclius and is dated in the reverse inscription to the year $\mathrm{I} \Gamma[=\mathrm{I} 3]$ of an indictional cycle. During Heraclius' long reign, this could correlate with either $\mathrm{AD} 624 / 5$ or $\mathrm{AD} 639 / 40$ (Grierson I968, 345, 347). Hahn (I98I, 218-9) preferred the later date for this issue.

59. Lafaurie I962; Morrisson I988a, 42. For further detail, see Discussion section.

60. Grierson I950b.

6I. Poinssot and Lantier 1925; Morrisson 1982. 
Table I. Sixth/seventh-century Carthage-mint (CTG) solidi by decade, from Bellinger's (I966) and Grierson's (1968) Dumbarton Oaks catalogues. The Carthage mint commenced issue of solidi in 534, and ceased to operate under Byzantine control $c$ 695. Selected data for the Constantinople mint

(CPL) are appended for comparison

\begin{tabular}{|c|c|c|c|c|c|}
\hline Mint & Date AD & No. coins & Mean wt & Mean diam. & Mean thickness ${ }^{\star \star}$ \\
\hline CTG & $534-45$ & 9 & $4.42 \mathrm{~g}$ & $\mathrm{I} 9.8 \mathrm{~mm}$ & $c \mathrm{I} . \mathrm{Omm}$ \\
\hline CTG & $565-78$ & $2 \mathrm{I}$ & $4.43 \mathrm{~g}$ & $20.1 \mathrm{~mm}$ & $c 0.9 \mathrm{~mm}$ \\
\hline CTG & $582-92$ & IO & $4.43 \mathrm{~g}^{\star}$ & $\mathrm{I} 9.3 \mathrm{~mm}$ & $c \mathrm{I} . \mathrm{Imm}$ \\
\hline CTG & $593-602$ & IO & $4.43 \mathrm{~g}$ & I8. Imm & $c \mathrm{I} .2 \mathrm{~mm}$ \\
\hline CTG & $603-10$ & 8 & $4.4 \mathrm{Ig}$ & I7.Imm & $c \mathrm{I} .3 \mathrm{~mm}$ \\
\hline CTG & $61 I-20$ & IO & $4.47 \mathrm{~g}$ & $\mathrm{I} 3.8 \mathrm{~mm}$ & c $2.3 \mathrm{~mm}$ \\
\hline CTG & $62 \mathrm{I}-30$ & II & $4.43 \mathrm{~g}$ & $\mathrm{I} 2.4 \mathrm{~mm}$ & c $2.8 \mathrm{~mm}$ \\
\hline CTG & $63 \mathrm{I}-40$ & II & $4.42 \mathrm{~g}^{\star}$ & II.Imm & $c 3.2 \mathrm{~mm}$ \\
\hline CTG & $64 \mathrm{I}-50$ & I4 & $4.38 \mathrm{~g}$ & II $.5 \mathrm{~mm}$ & $c 3.0 \mathrm{~mm}$ \\
\hline CTG & $65 \mathrm{I}-60$ & I 2 & $4 \cdot 37 \mathrm{~g}$ & II. $3 \mathrm{~mm}$ & c $3 . \mathrm{Imm}$ \\
\hline CTG & $66 \mathrm{I}-70$ & 6 & $4 \cdot 33 \mathrm{~g}$ & II. $7 \mathrm{~mm}$ & c $2.9 \mathrm{~mm}$ \\
\hline CTG & $67 \mathrm{I}-80$ & II & $4 \cdot 33 \mathrm{~g}$ & I3. Imm & $c 2.6 \mathrm{~mm}$ \\
\hline CTG & $68 \mathrm{I}-95$ & 6 & $4 \cdot 33 \mathrm{~g}$ & $\mathrm{I} 4.0 \mathrm{~mm}$ & $c 2.3 \mathrm{~mm}$ \\
\hline CPL & $527-38$ & IO & $4 \cdot 39 \mathrm{~g}$ & $20.5 \mathrm{~mm}$ & $c 0.9 \mathrm{~mm}$ \\
\hline CPL & $565-78$ & $2 \mathrm{I}$ & $4.43 \mathrm{~g}$ & $20.5 \mathrm{~mm}$ & $c 0.9 \mathrm{~mm}$ \\
\hline CPL & $629-31$ & 12 & $4.42 \mathrm{~g}$ & $20.7 \mathrm{~mm}$ & $c 0.9 \mathrm{~mm}$ \\
\hline CPL & $705-11$ & 22 & $4.23 \mathrm{~g}$ & $\mathrm{I} 9.9 \mathrm{~mm}$ & $c \mathrm{I} . \mathrm{Omm}$ \\
\hline
\end{tabular}

Notes: ${ }^{\star}$ These averages each exclude one light-weight specimen (Dumbarton Oaks nos Maurice 216 and Heraclius 222.2), authenticity of which was questioned by the cataloguers. $\star \star$ Thicknesses, not recorded in the Dumbarton Oaks catalogues, have been calculated by the author of this paper on the basis of volume and recorded diameter, assuming circular blanks in 98 per cent gold.

specialist English-language literature as 'globular' solidi' ${ }^{62}$ There is virtual unanimity among numismatists that the main series was minted at Carthage between the second and the tenth decades of the seventh century; this is indicated by the distribution of recorded finds ${ }^{63}$ and is also, as will be shown below, in accord with the period when this mint continued in operation under Byzantine control. Sixth-century solidi had been remarkably uniform in design and general appearance throughout the Empire, struck on flans between 19 and $2 \mathrm{Imm}$ in diameter and $c 0.8 \mathrm{~mm}$ in thickness. Globular solidi, by contrast, measured between II and $15 \mathrm{~mm}$ in diameter and as much as $c 3.2 \mathrm{~mm}$ thick, while maintaining with only minimally decreased precision the weight-standard followed elsewhere (table I). The globular solidi maintained their weights, despite changes in size and configuration.

In the mid-seventh century, under Constans II, the number of mints striking gold coins was much reduced, resulting in greater overall prominence for the Carthage issues. ${ }^{64}$ It was at one time believed that two distinct series of solidi were minted at seventh-century Carthage: one globular and one retaining the size and fabric of earlier times, the latter being

62. Grierson 1982, I22-5. See also figs $4 \mathrm{~b}-\mathrm{e}, 5$ and 6, tables I and 2.

63. For example, Grierson 1953; Whitting 1966.

64. Grierson I968, 4I2. 


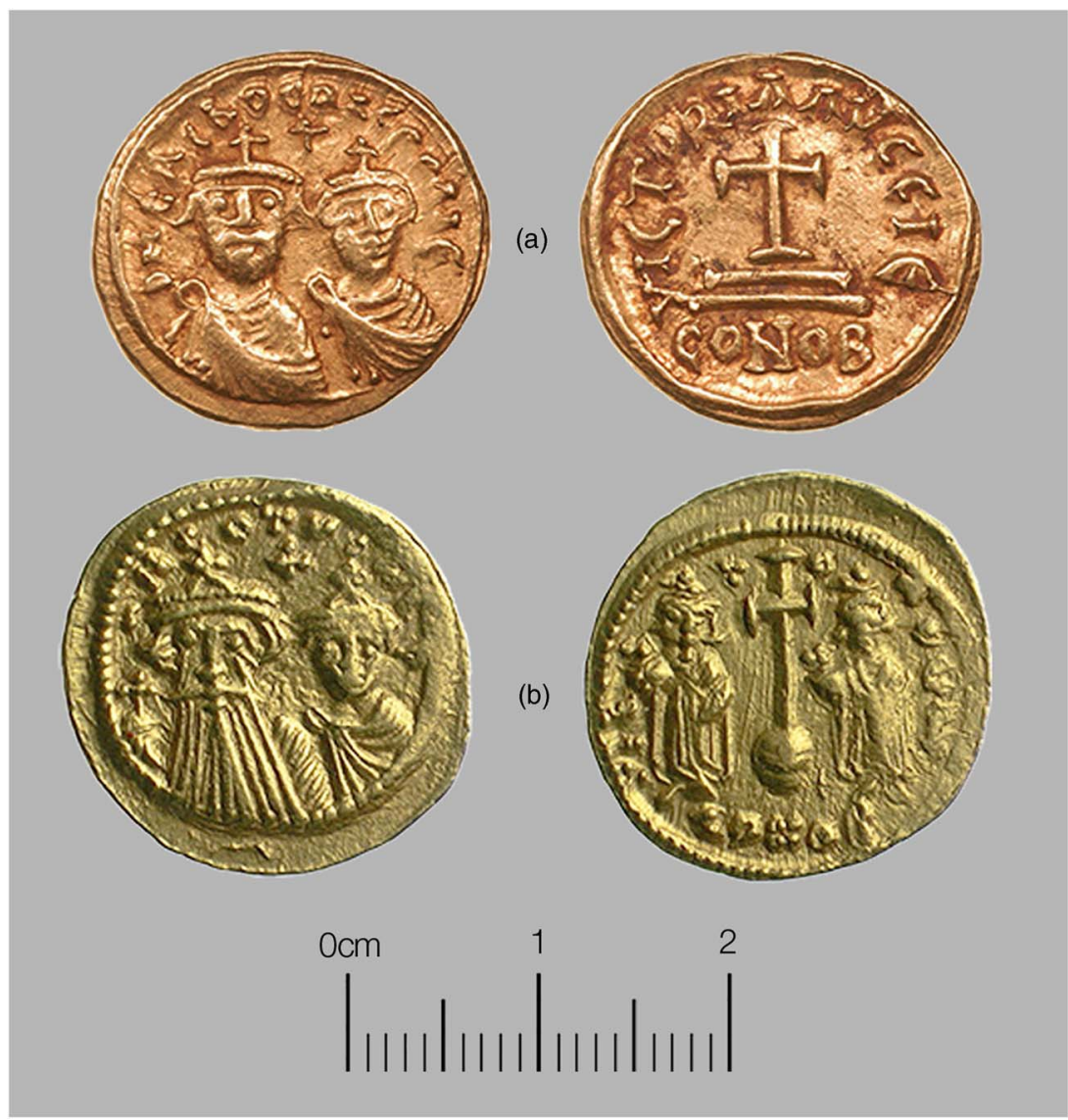

Fig 5. Solidi attributed to the Carthage mint on stylistic grounds, but struck on regular flans: a) Heraclius and Heraclius Constantine (MIB 9I-3, 4.39g), indiction IB = I2 (623/4); b) Constans II and Constantine IV (MIB 75, 4.34g), indiction unclear but $654-68$. 'MIB' references are to the type numbers in Hahn (I98I). Note that all coins illustrated in this paper are shown at exactly the same scale. Photograph: courtesy of the Barber Institute of Fine Arts, University of Birmingham.

illustrated in figure $5 .{ }^{65}$ It was likewise considered that not all globular solidi originated at Carthage, some being attributed to Constantine (formerly Cirta) in modern Algeria, and to mints in Sardinia and Sicily. More recent scholarship has questioned these assumptions, without always presenting the underlying evidence. ${ }^{66} \mathrm{~A}$ consensus has emerged, however, and is followed in this paper, that all Carthage solidi were globular, and that all globular solidi minted before 695 were produced at Carthage. ${ }^{67}$

65. For example, Wroth I908, ci; see also Grierson I968, 43.

66. See, for example, Sear 1987, I86, 214-15; Morrisson I988b, 427. Grierson I999 cited globular solidi as a defining characteristic of the Carthage mint during the seventh century, but provided no further mention or explanation.

67. See nn 88 and 95 for discussion of the possibility that similar globular solidi were subsequently minted in Sardinia. 
As noted above, the Carthage mint followed a tradition of precise dating for its gold coins, generally according to the indictional system. ${ }^{68}$ This permits recognition of precise dates for the rapid adoption and subsequent development of globular solidi. Coins produced during the decades following the establishment of the Carthage mint under Justinian I $c 533 / 34$, and again between 567/68 and the end of the sixth century, were effectively identical in fabric to those issued elsewhere. ${ }^{69}$ The transition to globular solidus production appears not to have been abrupt, but to have taken place gradually over a period of four or five decades from the 580 os to the 620s. Until AD 6IO, this process was slow and hesitant, but in the following two decades it accelerated markedly. During the second and third decades of the seventh century - as table I indicates - the diameters of globular solidi were subject to a steady but marked reduction, reaching a mean of I I-I $2 \mathrm{~mm}$ from $c 630$ until $c 670$ before slightly increasing once again during the final quarter-century of operation by the Byzantine mint at Carthage. ${ }^{70}$

Globular solidi were struck in the names of the following rulers: ${ }^{7 \mathrm{I}}$

6IO-4I Heraclius (see Byzantine Coinage section). From 6I3 he ruled jointly with his son, Heraclius Constantine, and, from 638, also with the latter's half-brother Heraclonas.

64I-68 Constans II, who had been known as Constantine III before the death of his father, Heraclius Constantine in 64I. Latterly, he ruled jointly with his sons: Constantine IV from 654, and also Heraclius and Tiberius from 659.

668-85 Constantine IV ruled jointly with his brothers Heraclius and Tiberius until 68I, when he deposed them and reigned alone.

685-95 Justinian II. $^{72}$

Semisses and tremisses were only very rarely struck at Carthage during the seventh century, ${ }^{73}$ but the few known examples shared many features with the globular solidi, approaching and occasionally even exceeding their diameters but not of course their weights. Special blanks for the fractional denominations must sometimes have been available, along with dies in appropriate designs for striking them. ${ }^{74}$

68. See Byzantine Coinage section. Indictional dates were indicated by letters at the end of the coin's inscription, usually on the reverse, but occasionally on both sides of the same coin; specimens are also known of 'mules' where the dies had become mixed, resulting in the date on the obverse being different from that on the reverse (Sear 1987, I86).

69. There seems to have been an unexplained hiatus between $\mathrm{AD} 548$ and 565 when no gold coins were produced at Carthage, although issue of copper denominations continued (Bellinger 1966, I59, 252; Morrisson I988a). For further detail, see Discussion section.

70. Longuet I96I, 8. These broader, but nonetheless globular, solidi issued AD 670-95 (for example, figs $4 \mathrm{e}$ and $6 \mathrm{~b}$ ) are much rarer and seem to have escaped notice by some commentators (for example, Morrisson 2002).

7I. These rulers, from Heraclius to Justinian II, represented the so-called Heraclian dynasty. Their limited repertoire of names, and the tender ages at which some of them became emperor, encourage confusion. A useful survey of Byzantine history at this period has been provided by Haldon (I990).

72. This was the first reign of Justinian II, who was deposed in 695, but returned to the throne a decade later when coins were again struck in his name 705-II, but only at Constantinople and at mints in Italy (including Sicily and, less certainly, Sardinia).

73. Grierson 1982, I22; Jonson et al 2014, 657. Both denominations were occasionally struck at Carthage in very small numbers under both Heraclius and Constans II. For a semissis of Constans, see Bateson and Campbell 1998, 67 and $\mathrm{pl}$ 10, 20.

74. The requirement of distinctive designs for fractional denominations prevented use of solidus dies despite similarity of diameter with the heavier coins. The implications of these observations are further discussed in n. IOI. 


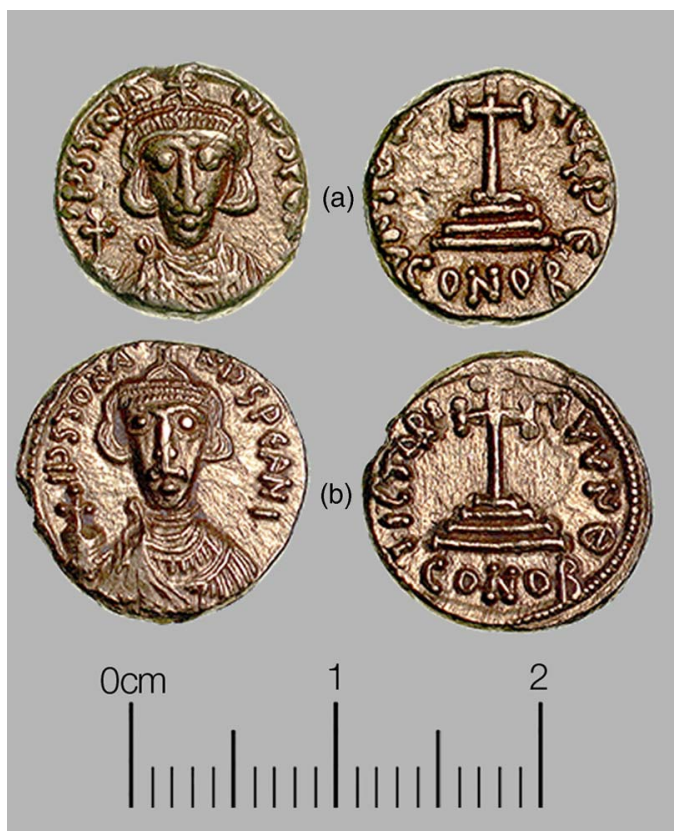

Fig 6. The final output of the Byzantine mint at Carthage: globular solidi struck under the first reign of Justinian II: a) MIB I8a (4.44g), indiction $\varepsilon$ [69I/2]; b) MIB I $8 \mathrm{~b}(4.32 \mathrm{~g})$, indiction $\theta$ [695/6]. 'MIB' references are to the type numbers in Hahn 198I. Note that all coins illustrated in this paper are shown at exactly the same scale. Photograph: courtesy of the Barber Institute of Fine Arts, University of Birmingham.

It is now appropriate to compare globular solidi with those - here termed 'regular' produced at Carthage in earlier times and at other Byzantine mints through the seventh century (see figs 4 and 6, tables I and 2). An essential difference concerned the blanks on which they were struck. Despite the tendency of some numismatists ${ }^{75}$ to use the terms interchangeably, here 'blank' is regarded as a generic term, with 'flan' referring specifically to a prepared disc with flat surfaces. The flans employed for production of regular solidi varied slightly in diameter but were remarkably standardised in weight. With occasional exceptions, they were produced in near-circular form. Despite not infrequent roughness or irregularity of the edges, their faces were remarkably flat and smooth (see, for example, fig 4a). Production at some mints could be quite careless, with significant numbers of solidi struck off-centre and with excessive or uneven pressure sometimes resulting in edge-cracks.

Minting of globular solidi and their fractions was markedly different. In all cases, dies were produced at a size that took account of the diameters of the blanks on which they were to be employed. Design-areas on dies for regular solidi averaged $250 \mathrm{~mm}^{2}$, while those used for striking the thickest globular examples had only 40 per cent of this area $\left(\right.$ Ioomm $\left.^{2}\right)$. Regular solidi were usually struck with dies slightly smaller in diameter than their flans (see, for example, fig 4a). Changes in diameter of the globular coins were, however, accompanied by closely corresponding changes in the dies, strongly suggesting that the latter items were

75. For example, Grierson 1975, I94; Butcher and Ponting 2014, 776. 
Table 2. Features of 'regular' and globular solidi compared

\begin{tabular}{|c|c|c|}
\hline Feature & Regular solidi & Globular solidi \\
\hline Blank/flan diameter & flan, $c 20-2 \mathrm{Imm}$ & blank, >I Imm \\
\hline Profile and surface of blank/flan & flat, smooth & $\begin{array}{l}\text { plano-convex, granular texture most } \\
\text { noticeable on the convex obverse }\end{array}$ \\
\hline Die diameter & $\begin{array}{l}\text { c } \mathrm{I} 8 \mathrm{~mm}: 2-3 \mathrm{~mm} \\
\text { smaller than flan }\end{array}$ & $\begin{array}{l}\text { > I I-I } 2 \mathrm{~mm} \text {, obverse slightly larger; } \\
\text { reverse slightly smaller than blank }\end{array}$ \\
\hline Striking & high pressure, variable & low pressure, careful \\
\hline Off-centre & often & rarely \\
\hline Border visible & usually, at least in part & obverse rarely; reverse usually \\
\hline
\end{tabular}

produced at Carthage itself, where for the most part they continued the tradition of precise dating (see Byzantine Coinage section) that had been established there since the late sixth century.

In many instances, the overall designs of the globular solidi remained the same as those employed at other mints; ${ }^{76}$ the process of producing dies must therefore have been subject to centralised direction following established practice, ${ }^{77}$ although difficulty was clearly experienced in engraving the more complex designs - particularly those of obverses showing two portraits side-by-side - within the very much smaller area that was available on the Carthage dies. This problem evidently became unsurmountable during the later part of Heraclius' reign, as discussed for Classes III-V in n. 76. There are no globular solidi of these types; the die-sinkers evidently recognised the impossibility of reducing the ordained designs to the diameter imposed by the globular fabric of their coins and, alone among the imperial mints, continued to follow the design that had prevailed previously. ${ }^{78}$ The simpler designs

76. It would be misleading to assume that solidi were minted at Carthage in each year, since there appear to be gaps in the recorded indictions, especially during the second half of the seventh century. Furthermore, particularly during the reign of Heraclius, Carthage did not follow all the design changes that were made at other mints. For example, at Constantinople - where solidi were produced in much larger numbers than elsewhere - a typological sequence of Heraclius' five obverse-types may be discerned (Grierson 1968, 254-63):

Class I: single bust of Heraclius, with short beard (6I0/1 I-6I2/13)

Class II: two busts: Heraclius larger, on left, with short beard; Heraclius Constantine on right, smaller and beardless (see fig $4 \mathrm{a}$ and b; type introduced in 612/13)

Class III: as last, but Heraclius with long beard (type introduced at Constantinople $c$ 629)

Class Iv: three standing figures: Heraclius in centre, crowned and with long beard; Heraclius Constantine to right, crowned and beardless; Heraclonas to left, without crown, and often much smaller than the others (type introduced at Constantinople $c$ 632)

Class v: as last, but all three figures are the same size and crowned ( $c$ 638-640/I at Constantinople).

The dates when Classes III and IV were introduced at Constantinople cannot be precisely ascertained, but it is noteworthy that no globular solidi are recorded of Classes III, IV or v, although the transition from Class I to Class II in 612/13 is confirmed by the coins' indictional dates. Since the indictional sequence of Heraclius' globular solidi shows no major interruptions, it seems that Class II continued at Carthage throughout his reign, Classes III, IV and $\mathrm{v}$ being never issued there.

77. See Byzantine Coinage section and also Grierson I950a.

78. See n. 76. The situation described above did not, however, continue under Constans II. For his reign, five successive solidus types may be recognised at Constantinople, all of which are also attested at Carthage (Grierson I968, 468-74):

Class I: Single bust, beardless $(64 \mathrm{I} / 2-647 / 8)$ 
prescribed at this time for the reverses of solidi did not present such problems, and it was presumably for this reason that the Carthage mint tended to employ reverse-dies slightly smaller than those used for the obverses (see, for example, fig $4 \mathrm{~b}-\mathrm{e}$ ). Similar problems were encountered with the inscriptions: these are often garbled and incomplete, with some letters ill-formed. They are often difficult to read, particularly on the convex obverses where peripheral parts of the designs were weakly struck.

So far as the author is aware, little - if any - research has been undertaken on the methods employed in the production of blanks for Byzantine gold coins, ${ }^{79}$ but this now requires brief consideration for both regular and globular solidi. The remarkably flat faces of regular-solidus flans, reflected also in the configuration of the dies, ${ }^{80}$ are readily observed; the flans were evidently made from carefully prepared metal sheet. The crosssections of globular solidi, by contrast, are plano-convex; ${ }^{8 \mathrm{I}}$ their reverses, like those of their regular counterparts, were essentially flat, but the obverses were in most cases convex, being evidently struck from slightly concave dies intended to accommodate the shape of the blanks. The marked but progressive changes in the diameters of globular solidi were highly uniform over time, being mirrored in those of the dies employed for striking them.

The size and configuration of the globular solidi meant that greater care had to be exercised in use of the dies, and uneven or off-centre strikes are only exceptionally encountered (see table 2). ${ }^{82}$ Another contrast with regular solidi is that the thicker blanks employed at Carthage had rougher, granular surfaces, this distinction being clearly visible on the coins themselves, most noticeably on their obverses (figs $4 \mathrm{~b}-\mathrm{e}$ and 6 ). This feature on globular solidi, discussed in more detail in the Discussion section, is distinct from that sometimes seen on other ancient coins and attributed to the use of rusty dies.

Class II: Single bust, short beard (648/9-652/3; see fig 4c)

Class III: Single bust, long beard (652/3-654/5)

Class Iv: two busts: Constans on left with long beard; Constantine Iv on right, beardless; cross on reverse $(653 / 4-658 / 9$ fig $4 \mathrm{~d})$.

Classes v and vi: as last, but busts of Heraclius and Tiberius on reverse (presumably 658/9 onwards).

For Constantine Iv, globular solidi (see fig 4e) are known only for the period before 68I/2 (Hahn I98I, nos I7-28). Carthage-mint gold coins for this and the following reign are significantly rarer than their earlier counterparts, and it may be that the mint's supplies of gold became less regular after 68I.

Under the first reign of Justinian $\mathrm{n}$, Constantinople and some other mints issued two distinct designs of solidus: one with the imperial portrait on the obverse, the other with a bust of Christ in that position. It is noteworthy that the latter coins - those depicting Christ - had no counterparts at Carthage. Morrisson and Kampmann 1979 drew attention to a Carthage-minted coin dated to $695 / 6$, further examples of which have since been recorded by Hahn (I98I, no. I8b = fig $6 \mathrm{~b}$ here) and by Goldberg and Goldberg (2009, lot 2,178), which continued the type that had seemingly been already discontinued at Constantinople.

79. Most research on the production of ancient coins has focused on dies and their use (for example, Vermeule 1954; Sellwood 1963, 1976) or, more recently, on metallurgy (for example, Ponting et al 2003; Butcher 2004, I29; Butcher and Ponting 2014, 130-47). Remarkably little attention has been paid to ascertaining how the blanks were produced.

80 . The coin illustrated in fig 4 a shows this feature particularly clearly.

$8 \mathrm{I}$. For further discussion, and justification for use of this term, see n. IOI.

82. The author is not aware of any studies addressing the question of possible innovations to the striking process in order to accommodate blanks of different form. Pegged dies, where pegs set outside the coin-striking area of one die fitted into sockets similarly placed in the other, would be the easiest way of achieving this. So far as the author is aware, the oldest surviving pegged die was used at a Maghreb mint to strike Almoravid dinars early in the twelfth century, as described by Grierson (1952) who proposed - without explanation - that this indicated a practice of significantly greater antiquity. Study of die-alignment should throw further light on this topic. 
Having outlined the ramifications of the rapid adoption at Carthage of globular solidi, it is now necessary to consider why this change took place. This is a question that has received remarkably little attention either from numismatists or from historians; most writers who mention the phenomenon at all have limited themselves to simple description. Adoption of globular solidi appears to have been independent of the revolt of the Heraclii.

Grierson's observation that 'at other periods in history coins have sometimes been made of an abnormal shape in the hope of checking their export, and this may have been the case here $^{, 83}$ is supported neither by what is known about well-established Byzantine currencymanagement policies ${ }^{84}$ nor by the circumstances of increasing isolation at Carthage, noted below in the Discussion section. More recently, Morrisson has argued that the striking of globular solidi required very much less energy than the regular fabric necessitated, ${ }^{85}$ but that 'numismatists can only speculate about the reasons for this particular way of economizing'. 'Two hypothetical reasons may be proposed: firstly, the moneyers needed, or wished, to increase productivity; and second they may have tried to decrease diewear. ${ }^{86}$

A broader historical perspective, however, permits a different interpretation. Evidence has been cited above that supply of gold to Carthage may have been interrupted as early as the mid-sixth century. ${ }^{87}$ Two significant developments that took place during the period 610-30 (coinciding precisely with the development of globular solidi) were completion of the Visigothic conquest of formerly Byzantine Spain $c$ 625, and the inception of Arab penetration through North Africa, beginning in Egypt. Both these developments would have caused serious disruption to Carthage's access to Byzantine-controlled sources of gold. It is postulated below that gold was brought from sudanic West Africa across the Sahara to Carthage in order to replace supplies that were no longer available. In view of the conclusions reached above in relation to the distinct blanks employed at Carthage for minting globular solidi and their fractions, further consideration of these matters in the wider context of seventh-century North Africa is postponed to the Discussion section of this paper.

\section{COINAGE AND BYZANTINE/ARAB INTERACTION IN NORTH AFRICA}

The issue of globular solidi by the Byzantine mint at Carthage gave rise to features of the region's coinage that survived long after the local eclipse of Byzantine political authority. Shortly before the closure of the Carthage mint, it seems that a new facility was established, perhaps located (although, to this author, the published evidence seems inconclusive) in

83. Grierson 1968, 234.

84. See Hendy 1970, 1972, I985, especially 409-24, and 1989b; Morrisson 2002. A possible exception, duly noted by Hendy (1985, 29I, I989a) is the edict of Constantius II and Julian, Codex Theodosianus IX.23.I.

85. Morrisson's conclusion $(2002,934)$ was based on research conducted more than 30 years ago by $F$ Delamare and P Montmitonnet, which represents, so far as the author is aware, the only attempt to investigate in any detail how and why the highly unusual globular solidi were produced. This aspect of their work was based, however, on only three specimens selected by Morrisson from the collections of the Bibliothèque nationale de France (Delamare and Montmitonnet 1984, I985; Delamare et al I988). These writers were able to point out that globular solidi could be struck with far less expenditure of force than could those of the usual thinner form, but they did not emphasise that their calculations assumed similarity in the available blanks, nor did they consider factors that might have led to lack of such similarity.

86. Delamare et al 1988, 47.

87. See nn 59 and 69. 
Sardinia, producing Byzantine-type solidi which, while not globular to the same extent as the Carthage issues, were nonetheless markedly thicker and correspondingly smaller in diameter than those produced elsewhere. This putative Sardinian mint seems to have ceased production late in the second decade of the eighth century. ${ }^{88}$

Rare, but particularly interesting, gold coins were struck both in North Africa and in Spain during the period immediately following the closure of the Byzantine mint at Carthage. ${ }^{89}$ Their designs were clearly based on those of seventh-century Byzantine issues, but the reverse representation of a cross on steps was 'de-Christianised' by omitting the horizontal bar or by replacing the whole upper part with a globe. Some issues replicated the earlier obverse portrayal of two rulers - Heraclius and Heraclius Constantine (6I3-4I), or Constans II and Constantine IV (654-68). ${ }^{90}$ The inscriptions employed Latin letters, but were garbled: they have been ingeniously interpreted, some as abbreviated Latin translations of Islamic slogans more usually presented in Arabic, others as recording mintage in Africa or in Spain. An additional noteworthy feature of these issues is that they retain not only the thick fabric and granular surfaces of the seventh-century gold coins of Byzantine Carthage, but also the weights of the solidi and their fractional denominations semissis and tremissis - the fractions, in fact, forming a significantly larger proportion of the surviving specimens than was the case with the Carthage-mint Byzantine issues.

\section{DISCUSSION}

It is informative to view these dated developments against the broad framework of North and West African history. The establishment of a Byzantine mint at Carthage had clearly been central to Justinian's re-incorporation of the region into his Empire following the period of Vandal control 440-533. ${ }^{9 \mathrm{I}}$ The other Byzantine mint to operate on the African continent was at Alexandria; ${ }^{92}$ the Arab conquest of Egypt led to its eventual closure $c$ 646. ${ }^{93}$ To the west, in what is now Tunisia and adjacent parts of western Libya and northern Algeria, parts of the old province of Africa remained under nominal Byzantine control for half a century longer. ${ }^{94}$ As noted above in the Byzantine Coinage section, Emperor Heraclius (r. 6IO-4I) was the son of an exarch of Africa, based at Carthage where he had

88. Grierson 1968, 44, I982, I22; McCormick 1998, 30; Grierson and Travaini I998, 287. Grierson's attribution of these coins to Sardinia, based on the presence of a letter ' $S$ ' in the reverse field, has subsequently received some confirmation from study of recorded find-spots (I am grateful to Dr Marco Muresu for information and advice on this point).

89. Walker 1956; Balaguer 1979; Bates I995; Christides 2000, 65-6. In the literature, these coins have been varyingly designated 'Arab-Byzantine' and 'Arab-Latin'. The author doubts the relevance to this topic of the coins identified by Grierson (I95Oc) as 'barbarous imitations' of solidi of Constans II indicating 'the first Arab or Berber involvement' in the striking of coinage 'in North Africa'.

90. If a Carthage-mint prototype is assumed, the former model is ruled out by the length of beard shown on the larger bust (see Byzantine Coinage section and nn 76 and 78 ).

91. Despite its almost exclusive reliance on written sources, the magisterial survey of North African Byzantine history by Diehl (1896) remains valuable. A different emphasis has been provided by more recent writers (for example, Brett 1978; Frend 1978; Fenwick 2013; Fentress and Wilson 20I6; Stevens and Conant 20I6).

92. The author follows Hahn and others who discount the possibility that a mint at Constantine (formerly Cirta) in Algeria may have operated intermittently during the second half of the sixth century (see also Morrisson I988b, 427).

93. Grierson I982, II 7-I9.

94. Christides 2000; Jonson et al 2014, 657. 
seized power. By the time of his death, however, Arab expansion westward from Egypt had isolated Carthage and its province from the rest of the Byzantine Empire other than by sea. Consolidation of that expansion resulted during the final decade of the seventh century AD (late first century AH) in the conquest of Carthage with the rest of Byzantine Africa, and the establishment of Arab rule over the territory thenceforth called Ifriqiya. The Carthage mint was closed and coin production transferred to Qayrawan/Kairouan, initially continuing - it has been suggested - employment of operatives previously engaged under Byzantine auspices. ${ }^{95}$

The reflections of this scenario in the numismatic record are not hard to discern. During the sixth century and - in most regions of the Byzantine Empire - thereafter, the minting of gold coins was under strict central control, which required free movement of bullion for processing tax-receipts and for the frequent re-coinages that evidently took place. ${ }^{96}$ Only exiguous local sources of gold were known in Byzantine-controlled North Africa, and the Arab conquest seriously impeded communication between Carthage and the non-African parts of the Byzantine Empire. Such difficulties may, in fact, have begun as early as the sixth century, and may be reflected in the apparent cessation of gold issues from the Carthage mint during $548-65^{97}$ and in the slight reduction in solidus-diameters (but not weights) from the $580 .^{98}$ After at least the third decade of the seventh century, when the last areas of Spain that had remained under Byzantine control were captured by the Visigoths, ${ }^{99}$ the Carthage mint would have been obliged to seek a new source or sources from which gold could be imported. It is suggested here that trans-Saharan imports met this need, using gold that was cast, for export and apparently also for local circulation at Tadmekka and possibly elsewhere, into subspheroidal lumps or 'dumps' ${ }^{\text {IO० }}$ of a standardised weight calculated precisely to meet the needs of the Byzantine mint at Carthage.

Use of moulds made of coarse gritty clay, like those excavated at Tadmekka, would have imparted to the sub-spheroids the granular surface texture and plano-convex form noted above on the globular solidi minted at Carthage (see 'Globular' Solidi section). ${ }^{\text {Ior }}$ A corollary to this proposal is that export of gold to the Mediterranean world may have been undertaken at the instigation of its producers or processers rather than that of the ultimate users. If confirmed, this reconstruction would require major revision to current understanding of Saharan and sub-Saharan peoples' relationships with their ruling

95. Bates I995; Christides 2000, 64-6. See n. 88 for the possibility that a mint in Sardinia continued production of Byzantine-style globular solidi into the early eighth century.

96. Hendy 1972.

97. See n. 69.

98. See table I and n. 59.

99. Collins I995, 38-9, 2004, 64-9I.

I00. The possibility cannot be ruled out that some gold from sub-Saharan regions had reached North Africa even earlier. For 'dumps', see n. 37.

IOI. Metallurgical analyses, noted in the final section, support this hypothesis. Rehren and Nixon (20I4, 40) noted that castings from the Tadmekka moulds would have been 'lentil'-shaped. In my view, following Sellwood I963, they are likely to have been plano-convex 'dumps', the lower surface following the shape of the mould, and the upper one much flatter, taking its slight curvature from the meniscus on the surface of the molten gold. It seems likely that the metal was weighed out before being placed in the individual cavities of moulds that were subsequently heated; alternatively, it may have been melted in crucibles before being poured into the moulds, although in the latter case control of the sub-spheroids' individual weights would have been more difficult (see Sellwood 1976; also, Rehren and Nixon 2014). Only very rarely were the same techniques used to produce blanks from which smaller gold denominations could be struck; use of the same moulds (but less gold) would nonetheless have been possible. 
contemporaries in North Africa. Clarification of these arguments will require more precise dating for the Tadmekka moulds. ${ }^{\text {IO2 }}$

Long-distance transport across the desert, even for such a high-value commodity as gold, would have been highly dependent on the availability of the camel. There is general agreement that domestic camels were not widespread in the Sahara before the mid-first millennium AD. It seems that camels spread only slowly through North Africa from east to west, and that they were not represented in faunal assemblages from Carthage until the fifth century AD. ${ }^{\text {IO3 }}$

This paper presents archaeological, historical and numismatic arguments in support of a sub-Saharan source for the gold used during the seventh century AD at the Byzantine mint at Carthage for production of the coins known to numismatists as globular solidi. Further metallurgical research is needed to confirm the hypothesis and to identify more precisely what African region or regions may have yielded the gold concerned. This is far from being the first time that a plea had been made for metallurgical analyses as a means of resolving controversies about the trans-Saharan gold trade, but arguments are here presented that make such a strategy somewhat clearer.

\section{THE WAY FORWARD: ARCHAEOMETALLURGY ${ }^{104}$}

This paper is not the first to have developed arguments that point to the development of trans-Saharan traffic in gold during the second half of the first millennium. In particular, it is suggested here that the practice may have begun as early as the late sixth century $\mathrm{AD}$, and that the initial recipients of West African gold may have been Byzantine rather than Arab. How can this hypothesis be tested?

Several previous writers have argued for the potential of trace-element analysis, but attempts at implementation have not so far yielded conclusive results. Until the last two decades, studies were impeded by problems of sampling and analysis. ${ }^{\text {105 }}$ More recently, continued difficulties have involved problematic or unsuitable samples, including uncertainty about differences between gold from various West African sources, unwarranted assumptions that trans-Saharan trade was an Islamic-period innovation ${ }^{\text {I06 }}$ and inadequate consideration of the likelihood that gold from many numismatic sources may have become mixed in the course of repeated re-coinages.

This paper's focus on globular solidi indicates an avenue of enquiry that would - at least in part - be less susceptible to such constraints, while artefacts of known detailed provenance within West Africa ${ }^{107}$ might provide more appropriate comparanda than geological samples. Emphasis has been placed ${ }^{108}$ on the high degree of fineness maintained throughout the period when globular solidi were minted at Carthage, suggesting that the

I02. The radiocarbon determinations suggest an age between the mid-eighth and the mid-tenth centuries, but the excavator (Nixon et al $201 \mathrm{I}, \mathrm{I}, 537$ ) has suggested that the Tadmekka sequence may have begun before the eighth century (see nn 33 and 35). It should be noted that there are no earlier secure dates for worked gold in more southerly West African latitudes.

103. Brett and Fentress 1996, 205; Fentress and Wilson 2016.

I04. For comments and additions to this section, I am most grateful to Professors Kevin MacDonald and Marcos Martinón-Torres.

105. Garrard 1982; Messier 1974; Morrisson et al 1982, 1983; Guerra et al 1999; Morrisson 2002; Wilson 2012; Jonson et al 2014.

I06. Fomin I990; Gondonneau and Guerra I999; Gondonneau et al 2000.

107. For example, S K McIntosh 1995, 267; Guerra 2000; Gronenborn et al 2012.

I08. Jonson et al 2014, 668, 678. 
mint utilised gold that had been obtained by cementation of ore particles mined in a placer deposit, and that similar characteristics were detected in Arab-Latin coins (see Coinage and Byzantine/Arab Interaction in North Africa section) and in North African Umayyad dinars. It has also been noted ${ }^{\mathrm{IO}}$ that this may represent access to sources of gold in Ghana, Mali and Mauritania. None of these writers, however, has been able to cite firm metallurgical evidence linking the gold used for any North African coinage with a sub-Saharan source.

Preliminary pilot investigations, using portable X-ray fluorescence equipment, has been conducted on the coins illustrated in figure 4 of this paper and on specimens kindly made available by Dr Maria Vrij at the Barber Institute, the University of Birmingham. Although this work is still in progress, preliminary results already indicate that, at least from early in the reign of Constans II (64I-68), the gold employed for producing globular solidi was significantly distinct from that used at other Byzantine mints. ${ }^{\text {IIO }}$ Multiple readings from obverses and reverses of some globular solidi reveal differences that strengthen the conclusion offered in the Discussion section, concerning the use of blanks analogous to those that would have been produced in moulds such as those excavated at Tadmekka. Further research on these and related (not exclusively numismatic) topics is planned by Professors MacDonald and Martinón-Torres.

\section{ACKNOWLEDGEMENTS}

For valued assistance, including advice, information, access to collections, comments on drafts and the provision of illustrations, I am greatly indebted to, among others, His Majesty The Asantehene, Dr Rebecca Darley, Mr Peter Donald, Ms Charlotte Fox, the late Mr Brian Foxley, Professor Ian Freestone FSA, Mr Gordon Frimpong, Dr John Giblin, Professor Kevin MacDonald FSA, Professor Marcos Martinón-Torres, Professor Malcolm McLeod, Dr Alex Metcalfe, Dr Marco Muresu, Dr Sam Nixon, Ms Kate Owen FSA, Dr Laurel Phillipson, Dr Tacye Phillipson, Mr John Vessey and Dr Maria Vrij. Versions of this paper have been presented to the Institute of Archaeology at University College London, in Toulouse at a conference of the Society of Africanist Archaeologists and to the York Fellows group of the Society of Antiquaries of London; I and this paper have benefited greatly from comments made at those meetings. Lastly, the Editor of this journal and her anonymous referees have made comments and suggestions for which I am very grateful.

\section{ABBREVIATIONS AND BIBLIOGRAPHY}

\section{Abbreviations}

\section{DAE Deutsche Aksum-Expedition}

\section{Bibliography}

Austen, A 2010. Trans-Saharan Africa in World History, Oxford University Press, New York

Balaguer, A M 1979. 'Early Islamic transitional gold issues of North Africa and Spain',
American Numismatic Society Museum Notes, 24, 225-4I and $\mathrm{pl} 47$

Balmuth, M S 1975. 'The critical moment: the transition from currency to coinage in the

I09. Gondonneau and Guerra 2002, 582; Jonson et al 20I4, 680.

IIO. The proposed investigation will also focus on the possibility that these processes may have begun as early as the second half of the sixth century (see nn 59 and 69). 
eastern Mediterranean', World Archaeology, 6, 293-8

Balmuth, M S (ed) 200I. Hacksilber to Coinage, American Numismatic Society, New York

Bates, M L 1995. 'Roman and early Muslim coinage in North Africa', in M Horton and $\mathrm{T}$ Wiedemann (eds), North Africa from Antiquity to Islam, I2-15, University of Bristol Centre for Mediterranean Studies, Bristol

Bateson, D and Campbell, I G 1998. Byzantine and Early Medieval European Coins in the Hunter Coin Cabinet, Spink, London

Bellinger, A R 1966. Catalogue of the Byzantine Coins in the Dumbarton Oaks Collection and in the Whittemore Collection. Vol. I: Anastasius to Maurice (49I-602), Dumbarton Oaks Center for Byzantine Studies, Washington DC

Bovill, E W I968. The Golden Trade of the Moors, Oxford University Press, London

Brett, M 1978. 'The Arab conquest and the rise of Islam in North Africa', in Fage I978, 490-555

Brett, $M$ and Fentress, E 1996. The Berbers, Blackwell, Oxford

Brown, R (ed) I896. The History and Description of Africa, by Leo Africanus (trans J Pory, London, I600), Hakluyt Society, London

Butcher, K 2004. Coinage in Roman Syria, Royal Numismatic Society, London

Butcher, $\mathrm{K}$ and Ponting, M 20I4. The Metallurgy of Roman Silver Coinage from the Reform of Nero to the Reform of Trajan, Cambridge University Press, Cambridge

Christides, V 2000. Byzantine Libya and the March of the Arabs towards the West of North Africa, Hedges, Oxford

Collins, R 1995. Early Medieval Spain, 2nd edn, Macmillan, London

Collins, R 2004. Visigothic Spain, 409-7II, Blackwell, Oxford

Connah, G 2016. African Civilisations, 3rd edn, Cambridge University Press, Cambridge

Cuoq, J M 1975. Recueil des sources arabes concernant l'Afrique occidentale du VIII au $X V I^{e}$ siècle, Centre National de la Recherche Scientifique, Paris

Curtin, P D I973. 'The lure of Bambuk gold', fournal of African History, 14, 623-31

Delamare, $\mathrm{F}$ and Montmitonnet, P 1984. 'A mechanical analysis of coin striking', fournal of Mechanical Working Technology, Io, 253-7I

Delamare, F and Montmitonnet, P 1985. 'Evolution of coin-striking processes.
I: hammer-striking', fournal of Mechanical Working Technology, II, 37-52

Delamare, F, Montmitonnet, $\mathrm{P}$ and Morrisson, C 1988. 'A mechanical approach to coin striking: application to the study of Byzantine gold solidi', in W A Oddy and M Archbald (eds), Metallurgy in Numismatics: Vol. 2, 4I-53, Royal Numismatic Society, Special Publications No. 19, London (reprinted as paper XIII in Morrisson 1994)

Devisse, J I988. 'Trade and trade routes in West Africa', in M el-Fasi (ed), General History of Africa III, 367-435, Heinemann, London

Devisse, J I993. 'L'Or', in J Devisse et al (eds), Vallées du Niger, 344-57, Réunion des Musées Nationaux, Paris

Diehl, C I896. L'Afrique byzantine (533-709), Leroux, Paris

Dowler, A and Galvin, E R (eds) 20I I. Money, Trade and Trade Routes in pre-Islamic North Africa, British Museum Press, London

Fage, J D (ed) 1978. The Cambridge History of Africa II, Cambridge University Press, Cambridge

Fenn, T R, Killick, D J, Chesley, J and Ruiz, J 2009. 'Contacts between West Africa and Roman North Africa: archaeometallurgical results from Kissi, north-eastern Burkina Faso', in S Magnavita, M Wood, E Melchiore, R S Popelka-Filcoff and M D Glascock (eds), Crossroads: cultural and technological developments in first millennium BC/AD West Africa, II9-46, Africa-Magna, Frankfurt-am-Main

Fentress, E and Wilson, A 2016. 'The Saharan Berber diaspora and the southern frontiers of Byzantine North Africa', in Stevens and Conant 20I6, 4I-63

Fenwick, C 2013. 'From Africa to Ifriqiya: settlement and society in early medieval North Africa', Al-Mosaq, 25, 9-33

Fomin, A 1990. 'Silver of the Maghrib and gold from Ghana at the end of the VIII-IX centuries AD', in K Jonsson and B Malner (eds), Proceedings of the Sigtuna Symposium on Viking-Age Coinage, 69-75, Spink, London

Frend, W H C 1978. 'The Christian period in Mediterranean Africa', in Fage 1978, 410-89

Garrard, T F 1972-3. 'Studies in Akan goldweights', Transactions of the Historical Society of Ghana, 13, I-20, I49-62; 14, I-16, I49-68

Garrard, T F I980. Akan Weights and the Gold Trade, Longman, London

Garrard, T F I982. 'Myth and metrology: the early trans-Saharan gold trade', Fournal of African History, 23, 443-6I 
Garrard, T F I988. 'The historical background to Akan gold-weights', in C Fox (ed), Asante Brass Casting, I-I3, University of Cambridge African Studies Centre, Cambridge

Garrard, T F i989. Gold of Africa, Prestel, Munich

Georganteli, E and Cook, B 2006. Encounters: travel and money in the Byzantine world, Giles, London

Goldberg, I and Goldberg, L 2009. Catalogue of Sale 53, 25 May 2009, Goldberg Coins \& Collectables, Los Angeles

Gondonneau, A and Guerra, M F 1999. 'The gold from Ghana and the Muslim expansion', in S Young, M Pollard, P Budd and R Ixer (eds), Metals in Antiquity, 262-70, Archaeopress, Oxford

Gondonneau, A and Guerra, M F 2002. 'The circulation of precious metals in the Arab Empire', Archaeometry, 44, 573-99

Gondonneau, A, Roux, C, Guerra, M F and Morrisson, C 2000. 'La frappé de la monnaie de l'or à l'époque de l'expansion musulmane', in B Kluge and B Weisser (eds), Akten der XII Internationaler Numismatischer Kongress, I, 264-74, Staatlichte Museen, Berlin

Grierson, P I950a. 'Dated solidi of Marius, Phocas and Heraclius', Numismatic Chronicle, 6th ser, Io, 49-70

Grierson, P i950b. 'The consular coinage of "Heraclius" and the revolt against Phocas in 608-10', Numismatic Chronicle, 6th ser, Io, 7I-93

Grierson, P i950c. 'A barbarous North African solidus of the late seventh century', Numismatic Chronicle, 6th ser, Io, 30I-5

Grierson, P 1952. 'Pegged Venetian dies', Numismatic Chronicle, 6th ser, 12, 99-I05

Grierson, P 1953. 'A Byzantine hoard from North Africa', Numismatic Chronicle, 6th ser, I3, I46-8

Grierson, P 196r. 'Notes on the fineness of the Byzantine solidus', Byzantinische Zeitschrift, 54, 9I-7

Grierson, P 1968. Catalogue of the Byzantine Coins in the Dumbarton Oaks Collection and in the Whittemore Collection. Vol. 2: Phocas to Theodosius III (602-717), Dumbarton Oaks Center for Byzantine Studies, Washington DC

Grierson, P 1975. Numismatics, Oxford University Press, London

Grierson, P I982. Byzantine Coins, Methuen, London

Grierson, P 1999. Byzantine Coinage, Dumbarton Oaks Center for Byzantine Studies, Washington DC
Grierson, P and Travaini, L 1998. Medieval European Coinage. Vol. I4: Italy (III) South Italy, Sicily, Sardinia, Cambridge University Press, Cambridge

Gronenborn, D, Adderley, P, Ameje, J, Banerjee, A, Fenn, T and Liesegang, G 20I2. 'Durbi Takusheyi: a high-status burial site in the western central Bilad al-Sudan', Azania: Archaeological Research in Africa, 47, 256-7I

Guerra, M F 2000. 'A report on the composition of a gold bead from Gao', in T Insoll (ed), Urbanism, Archaeology and Trade: further observations on the Gao region, Mali, I53-5, Hedges, Oxford

Guerra, M F, Sarthre, C-O, Gondonneau, A and Barrandon, J-N I999. 'Precious metals and provenance enquiries using LA-ICPMS', fournal of Archaeological Science, 26, I,IOI-IO

Hahn, W I973-8I. Moneta Imperii Byzantini, 3 vols, Österreichische Akademie der Wissenschaften, Vienna

Hahn, W I981. Moneta Imperii Byzantini. Vol. 3: von Heraclius bis Leo III (6IO-720), Österreichische Akademie der Wissenschaften, Vienna

Haldon, J F 1990. Byzantium in the Seventh Century, Cambridge University Press, Cambridge

Haour, A 20I I. 'The early medieval slave trade of the central Sahel', Proceedings of the British Academy, 168, 6I-78

Hendy, M F 1970. 'On the administrative basis of the Byzantine coinage', University of Birmingham Historical fournal, 12, I29-54 (reprinted as paper VIII in Hendy I989c)

Hendy, M F 1972. 'Aspects of coin production and fiscal administration in the late Roman and early Byzantine period', Numismatic Chronicle, 7th ser, I2, II 7-39 (reprinted as paper $\mathrm{V}$ in Hendy $1989 \mathrm{c}$ )

Hendy, M F 1985. Studies in the Byzantine Monetary Economy, Cambridge University Press, Cambridge

Hendy, M F i989a. 'Economy and state in late Rome and early Byzantium', in Hendy I989c, paper I

Hendy, M F I989b. 'The administration of mints and treasuries, 4 th to 7 th centuries', in Hendy I989c, paper VI

Hendy, M F i989c. The Economy, Fiscal Administration and Coinage of Byzantium, Variorum, Northampton

Hewson, A D I980. 'The Ashanti weights: a statistical evaluation', fournal of Archaeological Science, 7, 363-70 
Insoll, $\mathrm{T}$ 2003. The Archaeology of Islam in sub-Saharan Africa, Cambridge University Press, Cambridge

Jonson, T, Blet-Lemarquand, $M$ and Morrisson, C 20I4. 'The Byzantine mint in Carthage and the Islamic mint in North Africa: new metallurgical findings', Revue numismatique, 171, 655-99

Kiéthéga, J-B I983. L'Or de la Volta noir, Karthala, Paris

Lafaurie, J 1962. 'Un solidus inédit de Justinien Ier frappé en Afrique', Revue numismatique, 6ème sér, 2, I67-82

Landon, M 2016. Making a Mint: comparative studies in late Iron Age coin moulds, Archaeopress, Oxford

Levtzion, N 1973. Ancient Ghana and Mali, Methuen, London

Levtzion, N and Hopkins, J F 1981. Corpus of Early Arabic Sources for West African History, Cambridge University Press, Cambridge (reprinted 2000, Wiener, Princeton)

Littmann, E et al 1913. Deutsche Aksum-Expedition, 4 vols, Reimer, Berlin

Longuet, H I96I. Introduction à la numismatique byzantine, Spink, London

MacDonald, K C 20II. 'A view from the south: sub-Saharan evidence for contacts between North Africa, Mauritania and the Niger, IOOO BC-AD 70', in Dowler and Galvin 20I I, $72-82$

Mattingly, D 20II. 'The Garamantes of Fazzan', in Dowler and Galvin 20II, 49-60

Mattingly, D J, Sterry, M J and Edwards, D N 2015. 'The origins and development of Zuwila, Libyan Sahara', Azania: Archaeological Research in Africa, 50, 27-75

Mattingly, D J, Leitch, V, Duckworth, C N, Cuénot, A, Sterry, $M$ and Cole, F (eds) forthcoming. Trade in the Ancient Sahara and Beyond, Cambridge University Press, Cambridge

Mauny, R 1961. Tableau géographique de l'ouest africain au moyen âge, Institut Fondamental daffier Noire, Dakar

Mauny, R I978. 'Trans-Saharan contacts and the Iron Age in West Africa', in Fage 1978, 272-34I

McCormick, M I998. 'The imperial edge: Italo-Byzantine identity, movement and integration $\mathrm{AD}$ 650-950', in $\mathrm{H}$ Ahrweiter and A E Laiou (eds), Studies on the Internal Diaspora of the Byzantine Empire, I7-52, Dumbarton Oaks Center for Byzantine Studies, Washington DC
McIntosh, R J and McIntosh, S K I98I. 'The inland Niger Delta before the Empire of Mali', Fournal of African History, 22, I-22

McIntosh, S K I98I. 'A reconsideration of Wangara/Palolus, Island of Gold', fournal of African History, 22, I45-58

McIntosh, S K (ed) 1995. Excavations at fennéFeno, Hambarketolo, and Kaniana (Inland Niger Delta, Mali), the 198I Season, University of California Press, Berkeley

McLeod, M D i98I. The Asante, British Museum Publications, London

Messier, R I974. 'The Almoravids: West African gold and the gold currency of the Mediterranean basin', Fournal of the Economic and Social History of the Orient, 17, 3I-47

Messier, R A and Miller, J A 20I5. The Last Civilized Place: Sijilmasa and its Saharan destiny, University of Texas Press, Austin

Metcalf, D M 1960. 'The metrology of Justinian's follis', Numismatic Chronicle, 6th ser, 20, 210-19

Mitchell, P J 2005. African Connections, Altamira Press, Walnut Creek, Calif

Morrisson, C 1970. Catalogue des monnaies byzantines de la Bibliothèque nationale, 2 vols, Bibliothèque nationale, Paris

Morrisson, C I982. 'Le trésor de monnaies d'or byzantines', in R Guéry, C Morrisson and $\mathrm{H}$ Slim (eds), Recherches archéologiques francotunisiennes à Rougga, Coll Ecole fran de Rome 60

Morrisson, C 1988a. 'Carthage: the moneta auri under Justinian I and Justin II, 537-578', in W Hahn and W E Metcalf (eds), Studies in Early Byzantine Gold Coinage, 4I-64, American Numismatic Society, New York

Morrisson, C I988b. 'Coin finds in Vandal and Byzantine Carthage', in J H Humphrey (ed), The Circus and a Byzantine Cemetery at Carthage, 423-36, University of Michigan Press, Ann Arbor

Morrisson, C 1994. Monnaie et finances à Byzance, Variorum, Aldershot

Morrisson, C 2002. 'Byzantine money: its production and circulation', in A E Laiou (ed), The Economic History of Byzantium, Dumbarton Oaks Studies 39, 909-66, Dumbarton Oaks Center for Byzantine Studies, Washington DC

Morrisson, C and Kampmann, M 1979. 'Le dernier solidus byzantin frappé à Carthage', Bulletin de la Société Française de Numismatique, 34, 5I4-I6

Morrisson, C, Barrandon, J-N, Brenot, C, Callu, J-P, Halleux, R and Poirier, J 1982. 'Numismatique et histoire : l'or monnayé 
de Rome à Byzance', Comptes rendus de l'Académie des Inscriptions et Belles-lettres, 1982, 203-23

Morrisson, C, Barrandon, J-N and Poirier, J I983. 'Nouvelles recherches sur l'histoire monétaire byzantine', fahrbuch der Österreichischen Byzantinistik, 33, 267-86 (reprinted as paper $\mathrm{x}$ in Morrisson 1994)

Nixon, S 2009. 'Excavating Essouk-Tadmakka (Mali): new archaeological investigations of early Islamic trans-Saharan trade', Azania: Archaeological Research in Africa, 44, 21 7-55

Nixon, S, Rehren, T and Guerra, M F 201 I. 'New light on the early Islamic West African gold trade: coin moulds from Tadmekka, Mali', Antiquity, 85, I,353-68

Phillips, J 20I I. 'The DAE small finds: a centenary postscript', in S Wenig (ed), In kaiserlichem Auftrag, 379-99, Reichert, Wiesbaden

Phillipson, D W 2005. African Archaeology, 3rd edn, Cambridge University Press, Cambridge

Poinssot, L and Lantier, R I925. 'Notes sur les fouilles executées en I924 dans les ruines de Thuburbo Majus', Bulletin archéologique du Comité des travaux historiques et scientifiques, année 1925, lxxi-lxxxv

Ponting, M, Evans, J A and Pashley, V 2003. 'Finger-printing of Roman mints using laser-ablation MC-ICO-MS lead isotope analysis', Archaeometry, 45, 59I-7

Price, M J 1983. 'Thoughts on the beginning of coinage', in C N L Brooke, B H I Stewart, J G Pollard and T R Volk (eds), Studies in Numismatic Method Presented to Philip Grierson, I-IO, Cambridge University Press, Cambridge

Rauchenberger, D i999. Fohannes Leo der Afrikaner: seine Beschreibung des Raumes zwischen Nil und Niger nach dem Urtext, Harrassowitz, Wiesbaden

Rehren, T and Nixon, S 20I4. 'Refining gold with glass: an early Islamic technology at Tadmekka, Mali', fournal of Archaeological Science, 40, 33-4I
Robinson, E S G I95I. 'The coins from the Ephesian Artemision reconsidered', fournal of Hellenic Studies, 71, I56-67

Sear, D R 1987. Byzantine Coins and their Values, Seaby, London

Sellwood, D I963. 'Some experiments in Greek minting techniques', Numismatic Chronicle, 7th ser, 3, 2I 7-3I

Sellwood, D I976. 'Minting', in D Strong and D Brown (eds), Roman Crafts, 63-73, Duckworth, London

Spufford, P 1988. Money and its Use in Medieval Europe, Cambridge University Press, Cambridge

Stevens, S T and Conant, J P (eds) 20I6. North Africa under Byzantium and early Islam, Dumbarton Oaks Center for Byzantine Studies, Washington DC

Swanson, J T I975. 'The myth of trans-Saharan trade during the Roman era', International Fournal of African Historical Studies, 8, 582-600

Vanacker, C I984. 'Perles de verre découvertes sur le site de Teghaoust', fournal des Africanistes, 54, 31-52

Vermeule, C 1954. Ancient Dies and Coining Methods, Spink, London

Walker, J 1956. Catalogue of the Arab-Byzantine and Post-Reform Umaiyad Coins in the British Museum, Trustees of the British Museum, London

Wansbrough, J I970. 'Africa and the Arab geographers', in D Dalby (ed), Language and History in Africa, 89-IoI, Cass, London

Whitting, P D I966. 'A seventh-century hoard at Carthage', Numismatic Chronicle, 7th ser, 6, 225-33 and $\mathrm{pl} \mathrm{xix}$

Whitting, P D I973. Byzantine Coins, Barrie and Jenkins, London

Wilding, R F 1989. 'The pottery', in S C MunroHay, Excavations at Aksum, 235-316, British Institute in Eastern Africa, London

Wilson, A 2012. 'Saharan trade in the Roman period', Azania: Archaeological Research in Africa, 47, 409-449

Wroth, W 1908. Catalogue of the Imperial Byzantine Coins in the British Museum, 2 vols, Trustees of the British Museum, London 